Article

\title{
Supplementation of Carbon-Based Conductive Materials and Trace Metals to Improve Biogas Production from Apple Pomace
}

\author{
Addam Claes ${ }^{1}$, Lucy Melchi ${ }^{1}$, Sibel Uludag-Demirer ${ }^{2}$ and Goksel N. Demirer ${ }^{1,3, *}$ \\ 1 School of Engineering and Technology, Central Michigan University, Mt. Pleasant, MI 48859, USA; \\ claes2am@cmich.edu (A.C.); melch2lm@cmich.edu (L.M.) \\ 2 Department of Biosystems \& Agricultural Engineering, Michigan State University, \\ East Lansing, MI 48824, USA; demirers@msu.edu \\ 3 Institute for Great Lakes Research, Central Michigan University, Mt. Pleasant, MI 48859, USA \\ * Correspondence: demir1g@cmich.edu; Tel.: +1-989-774-2456
}

Citation: Claes, A.; Melchi, L.; Uludag-Demirer, S.; Demirer, G.N. Supplementation of Carbon-Based Conductive Materials and Trace Metals to Improve Biogas Production from Apple Pomace. Sustainability 2021, 13, 9488. https://doi.org/ $10.3390 /$ su13179488

Academic Editor: Paolo S. Calabrò

Received: 20 July 2021

Accepted: 19 August 2021

Published: 24 August 2021

Publisher's Note: MDPI stays neutral with regard to jurisdictional claims in published maps and institutional affiliations.

Copyright: (c) 2021 by the authors. Licensee MDPI, Basel, Switzerland. This article is an open access article distributed under the terms and conditions of the Creative Commons Attribution (CC BY) license (https:// creativecommons.org/licenses/by/ $4.0 /)$.

\begin{abstract}
Due to its high water and organic contents, management of apple pomace (AP) poses several waste management challenges on the apple juice and cider producing industries. Bioconversion of AP into biogas provides an excellent possibility to reduce the environmental challenge faced in the management of AP waste along with producing renewable energy in the form of methane. This study investigated the effect of carbon-based conductive materials (biochar and graphene) and trace metals supplementation to improve biogas production from AP. The results indicate that supplementation of biochar, trace metals, and graphene significantly improves the biogas production from AP. Trace metal and biochar supplementation at a COD concentration of $6000 \mathrm{mg} / \mathrm{L}$ resulted in $7.2 \%$ and $13.3 \%$ increases in the biogas production, respectively. When trace metals and biochar were supplemented together, the biogas production increased by $22.7 \%$. This synergistic effect was also observed at the COD concentration of $12,000 \mathrm{mg} / \mathrm{L}$. The improvement in the biogas formation was significantly higher for graphene supplemented reactors (27.8\%). Moreover, biochar and trace metals supplementation also led to $19.6 \%$ and $23.0 \%$ increases in the methane yield relative to the reactor fed only with $\mathrm{AP}$, respectively. These results suggest anaerobic digestion supplemented with carbon-based conductive materials and trace metals is a viable option for valorizing apple pomace.
\end{abstract}

Keywords: anaerobic digestion; apple pomace; biochar; trace metals; graphene

\section{Introduction}

The valorization of waste produced by food processing plants is becoming an important contributor to the food industry and bioeconomy. The fruit processing industry generates large volumes of biological byproducts that could be used for manufacturing several value-added products [1]. Apple pomace (AP) is the main solid waste generated in cider and apple juice factories and represents $20-35 \%$ of the original fruits [2,3]. Every year, several million metric tons of residue are produced worldwide [4].

High water content (70-75\% moisture), high chemical oxygen demand (COD), biological oxygen demand (BOD), and easily fermentable forms of sugars make AP highly prone to microbial attack and thus unsafe for environmental disposal. Management of AP waste imposes substantial extra costs on apple-juice- and cider-producing industries. Although in some parts of the world AP is used as animal feed, this is not common practice in the majority of apple-producing countries. Alternatively, AP is dumped on open land areas and this causes environmental pollution $[1,5]$.

Gassara et al. [6] investigated different AP waste management scenarios along with the corresponding greenhouse gases (GHG) emissions produced. The scenarios evaluated were: (a) incineration; (b) landfill; (c) animal feed; (d) enzyme production by fermentation; (e) composting. To determine the balance of GHG emissions, life cycle analysis (LCA) was adopted. The results obtained in this study showed that enzyme production (906.81 
tons of $\mathrm{CO}_{2}$ equivalent per year) and animal feed (963.38 tons of $\mathrm{CO}_{2}$ equivalent per year) were the least polluting options of the environment in terms of GHG emissions, followed by incineration (1122.10 tons of $\mathrm{CO}_{2}$ equivalent per year), composting (1273.00 tons of $\mathrm{CO}_{2}$ equivalent per year), and landfill (1841.00 tons of $\mathrm{CO}_{2}$ equivalent per year). The results of this study clearly indicated that generating valuable and marketable products from AP does not only have economic value, it also reduces GHG emissions as well as other pollutants released in the environment relative to conventional waste management practices such as incineration, composting, and landfilling.

$\mathrm{AP}$ is rich in both soluble carbohydrates such as simple sugars (fructose, glucose, and sucrose) and polysaccharides (cellulose, hemicellulose, and pectin), showing high potential for further bio-conversion purposes [7-9]. In this context, bioconversion of AP into biogas provides an excellent possibility to reduce the environmental challenge faced in the management of AP waste while producing renewable energy in the form of methane. This practice is in agreement with sustainability, which calls for achieving closed-loop systems to maximize the recovery of bioenergy and bio-based materials derived from the waste at end-of-life. Therefore, the wastes should be considered as "renewable resources" that can be reused to generate valuable and marketable products, replacing non-renewable fossil-based resources $[9,10]$.

Anaerobic digestion (AD) of organic wastes is not only a waste management but also waste valorization technique that offers energy recovery, nutrient reclamation, as well as bio-based product generation [11-15]. AD of apple pomace has been investigated in a limited number of studies. In one of the earliest studies, Jewell and Cummings [16] stated that nearly $80 \%$ of pomace organics were converted into biogas with an energy value of \$10-30 per wet metric ton. Molinuevo-Salces et al. [8] reported methane yields up to $596 \mathrm{~mL} \mathrm{CH}_{4} / \mathrm{g}$ VS from co-digestion of AP and manure. Another study investigated biogas production from waste apple biomass and the highest average specific methane yield was reported as $0.451 \mathrm{~L} / \mathrm{g}$ dry organic matter [17].

Different pretreatment methods (ultrasound, thermal, and chemical) to improve the biogas generation from AP were also investigated. It was reported that ultrasound pretreatment $\left(53 \mathrm{kHz}\right.$ at $60^{\circ} \mathrm{C}$ for $\left.45 \mathrm{~min}\right)$ was the most effective pretreatment method and led to a $41 \%$ increase in biogas production [18]. AP was also anaerobically co-digested with slaughterhouse waste and swine manure, leading to significant biogas production levels $[19,20]$.

Even though anaerobic digestion is a cost-effective and widely used method for digesting several organic wastes and green energy recovery, it is a complicated microbial process, which may suffer from process instability and various inhibition problems [21,22]. Thus, several methods have been proposed to increase the efficiency of anaerobic digestion such as microwave, ozone, pretreatments, co-digestion, addition of carbon-based additives, trace elements, etc. [23-26]. Among these, pretreatment and co-digestion were already investigated for AP [18-20].

Biochar is a charcoal type of material, which is produced by pyrolysis of agricultural and animal-based biomass. Since it is a recycled product, it is considered a low-cost replacement of granular activated carbon (GAC) [27]. It was reported that biochar significantly improved the anaerobic digestion rate of food waste [28]. Moreover, biochar supplementation, in a mesophilic anaerobic reactor fed by butyrate, shortened the lag time, increased the maximum methane production rate, and showed remarkable buffering capacity to alleviate $\mathrm{pH}$ decrease [29].

Graphene is a mono-layered carbon nanostructure forming a hexagonal lattice. It possesses high electrical conductivity as well as high mechanical strength and thermal conductivity [30]. Although there are not many studies regarding the impact of graphene on anaerobic microbial communities, its electrical conductivity, large surface area, and mechanical strength may improve the stability and efficiency of anaerobic digestion process. Compared with GAC, there are few studies focused on graphene supplement in the AD process. Studies proved that the electrical conductivity of graphene promoted the direct 
interspecies electrons transfer (DIET) mechanism and increased the methane yield, methane production rate, and enriched the methanogenesis bacterial community [31,32].

The objective of this study was to investigate the effect of carbon-based conductive materials (biochar and graphene) and trace metals supplementation to improve biogas production from AP. To the best of our knowledge, this was not explored before. Biochemical methane potential (BMP) assays were conducted for AP in the absence and presence of carbon-based conductive materials (biochar and graphene) and trace metals. The biogas production and methane yields were determined.

\section{Materials and Methods}

\subsection{Anaerobic Seed}

Anaerobic seed was obtained from the anaerobic digester of Michigan State University in East Lansing, MI, USA. It was kept undisturbed at ambient temperature for starvation and solids settling. The supernatant was discarded, and the remaining sludge was used as anaerobic seed for BMP tests. The seed had a total and volatile solid (TS and TVS, respectively) concentration of 34,345 \pm 145 and 11,150 $\pm 1174 \mathrm{mg} / \mathrm{L}$, respectively. The total chemical oxygen demand (CODt) concentration of the seed was measured as $48,500 \pm 566 \mathrm{mg} / \mathrm{L}$ (Table 1).

Table 1. Characterization of anaerobic seed and apple pomace samples.

\begin{tabular}{ccc}
\hline Parameter & Seed & Apple Pomace \\
\hline CODt (mg/L) & $48,500 \pm 566$ & $73,000 \pm 90$ \\
CODs (mg/L) & - & $42,880 \pm 260$ \\
TS (mg/L) & $34,345 \pm 145$ & $15,700 \pm 830$ \\
VS (mg/L) & $21,150 \pm 1174$ & $9250 \pm 1250$ \\
TKN (mg/L) & $2750 \pm 71$ & $140 \pm 10$ \\
Total P (mg/L) & $650 \pm 71$ & $170 \pm 10$ \\
pH & 7.80 & 7.53 \\
\hline
\end{tabular}

\subsection{Apple Pomace}

Apple pomace was collected from two different apple cider mills located in Michigan. It was refrigerated at $4{ }^{\circ} \mathrm{C}$ prior to characterization and BMP assays. Total and soluble chemical oxygen demand (COD) of AP were 73,000 \pm 90 and 42,880 $\pm 260 \mathrm{mg} / \mathrm{L}$, respectively. TS and VS contents were $15,700 \pm 830$ and $9250 \pm 1250 \mathrm{mg} / \mathrm{L}$, respectively (Table 1).

\subsection{Conductive Materials}

The biochar was made from dried wastewater biosolids (i.e., Milorganite) composed of raw waste activated sludge and anaerobically digested primary sludge at the Milwaukee, WI, water resource reclamation facility (Jones Island WRRF). The dried biosolids were pyrolyzed at $700{ }^{\circ} \mathrm{C}$ for $15 \mathrm{~min}$ in a rotary pyrolyzer at Norris Thermal Technologies, Tippecanoe, IN. Graphene flake powder $(0.3-1 \mathrm{~nm})$ was obtained from AZ Laboratories.

\subsection{Analytical Methods}

Standard Methods were followed for TS (2540 B) and VS (2540 E) [33]. Chemical oxygen demand (COD) (HACH/EPA Method 8000), total Kjeldahl nitrogen (HACH/EPA Method 10072), and total phosphorus (HACH/EPA Method 8190) were determined by using Hach test kit vials (Hach, Loveland, CO, USA). During the BMP assays, biogas production in each reactor was measured by the water displacement method [34].

Biogas composition was quantified using a gas chromatography (GC) device (SRI Instruments, 310C, Torrance, CA, USA) equipped with FID and packed column HayeSep D (Agilent, 80/100, 1/8, 2 mm, Santa Clara, CA, USA) to detect $\mathrm{CH}_{4}$ content. The temperatures of the oven, injector, and detector were maintained at $150{ }^{\circ} \mathrm{C}$. Helium was employed as a carrier gas at a constant pressure of 21 psi. All quantifications were performed in triplicates. 


\subsection{Biochemical Methane Potential Assays}

Batch reactors with total and effective volumes of 250 and $150 \mathrm{~mL}$, respectively, were operated in the experiments. The anaerobic degradability and biogas production potential of the apple pomace samples with and without conductive materials and trace metals were determined.

The first experimental setup was run to determine the effect of biochar $(13.3 \mathrm{~g} / \mathrm{L})$ and trace metal supplementation on the $\mathrm{AD}$ of apple pomace. A control (seed only) and eight tests (seed, apple pomace, biochar, and/or trace metals) reactors were run in duplicates (Table 2). All reactors contained $4230 \mathrm{mg} / \mathrm{L}$ anaerobic seed as the VS and $6000 \mathrm{mg} / \mathrm{L} \mathrm{NaHCO}_{3}$ as the alkalinity source. Reactors T1 and T5 were operated only with apple pomace to determine its BMP at two different COD concentrations, 6000 and $12,000 \mathrm{mg} / \mathrm{L}$. Reactors T2 and T6 were operated to evaluate the effect of trace metals on the AD apple pomace. The effect of biochar was investigated in the absence (T3 and T7) and presence (T4 and T8) of trace metals (Table 2). Trace metal solution contained $100 \mathrm{mg} / \mathrm{L}$ $\mathrm{FeCl}_{2} \cdot 4 \mathrm{H}_{2} \mathrm{O}, 20 \mathrm{mg} / \mathrm{L} \mathrm{CoCl}_{2} \cdot 6 \mathrm{H}_{2} \mathrm{O}, 20 \mathrm{mg} / \mathrm{L} \mathrm{NiCl}_{2} \cdot 6 \mathrm{H}_{2} \mathrm{O}, 2 \mathrm{mg} / \mathrm{L} \mathrm{CuCl}_{2} \cdot 2 \mathrm{H}_{2} \mathrm{O}, 2 \mathrm{mg} / \mathrm{L}$ $\mathrm{ZnCl}_{2}, 6 \mathrm{mg} / \mathrm{L} \mathrm{Na}_{2} \mathrm{MoO}_{4} \cdot 2 \mathrm{H}_{2} \mathrm{O}$, and $2 \mathrm{mg} / \mathrm{L} \mathrm{NaWO}_{4} \cdot 2 \mathrm{H}_{2} \mathrm{O}$. Two different chemical oxygen demand (COD) concentrations were tested in the first experimental setup: 6000 (T1-T4) and $12,000 \mathrm{mg} / \mathrm{L}$ (T5-T8).

Table 2. Experimental setups used in the study.

\begin{tabular}{|c|c|c|c|c|c|c|}
\hline & Reactor * & Seed & $\begin{array}{c}\text { Apple } \\
\text { Pomace }\end{array}$ & $\begin{array}{c}\text { Trace } \\
\text { Metal } \\
\text { Solution }\end{array}$ & Biochar & Graphene \\
\hline \multirow{9}{*}{$\begin{array}{c}\text { First } \\
\text { Experimental } \\
\text { Setup }\end{array}$} & $\mathrm{C} 1$ & + & - & - & - & - \\
\hline & $\mathrm{T} 1$ & + & + & - & - & - \\
\hline & $\mathrm{T} 2$ & + & + & + & - & - \\
\hline & T3 & + & + & - & + & - \\
\hline & $\mathrm{T} 4$ & + & + & + & + & - \\
\hline & T5 & + & + & - & - & - \\
\hline & T6 & + & + & + & - & - \\
\hline & $\mathrm{T} 7$ & + & + & - & + & - \\
\hline & $\mathrm{T} 8$ & + & + & + & + & - \\
\hline Second & $\mathrm{C} 2$ & + & - & - & - & - \\
\hline Experimental & T9 & + & + & - & - & - \\
\hline Setup & $\mathrm{T} 10$ & + & + & - & - & + \\
\hline
\end{tabular}

The second experimental setup was run to determine the effect of graphene $(666.7 \mathrm{mg} / \mathrm{L})$ supplementation on the AD of apple pomace. A control (seed only) and two tests (seed, apple pomace, and graphene) reactors were run in duplicates (Table 2). All reactors contained $4230 \mathrm{mg} / \mathrm{L}$ anaerobic seed as VS and $6000 \mathrm{mg} / \mathrm{L} \mathrm{NaHCO}_{3}$ as the alkalinity source. Reactor T9 was operated only with apple pomace to determine its BMP at a COD concentration of 12,000 mg/L. Reactor T10 was operated to determine the effect of $666.7 \mathrm{mg} / \mathrm{L}$ graphene supplementation on the $\mathrm{AD}$ of apple pomace. The COD concentration in T10 was $12,000 \mathrm{mg} / \mathrm{L}$.

The AP-to-seed (on COD basis) and I:S (on VS basis) ratios were 1.25-2.50 and $1.37-2.74$, respectively. The average biogas production in the control reactors (C1) was subtracted from all test reactors.

The supplementation of carbon-based conductive materials and trace metals to improve anaerobic digestion of apple pomace was not investigated before. Therefore, the dosage of supplements used in this study were based on similar studies that investigated the effect of these supplements on anaerobic digestion for other substrates.

After addition of all the constituents, the $\mathrm{pH}$ values of the reactors were adjusted to $7.1 \pm 0.2$ by $2 \mathrm{~N} \mathrm{HCl}$ and $\mathrm{NaOH}$ solutions. Reactors were purged with $N$ gas for 4 min and capped with rubber septa. Immediately after purging, the reactors were incubated 
in an environmental chamber at $35 \pm 1{ }^{\circ} \mathrm{C}$ with constant mixing at $120 \mathrm{rpm}$. Daily gas production was measured by using a water replacement device (Figure 1) [13], and gas compositions were analyzed.
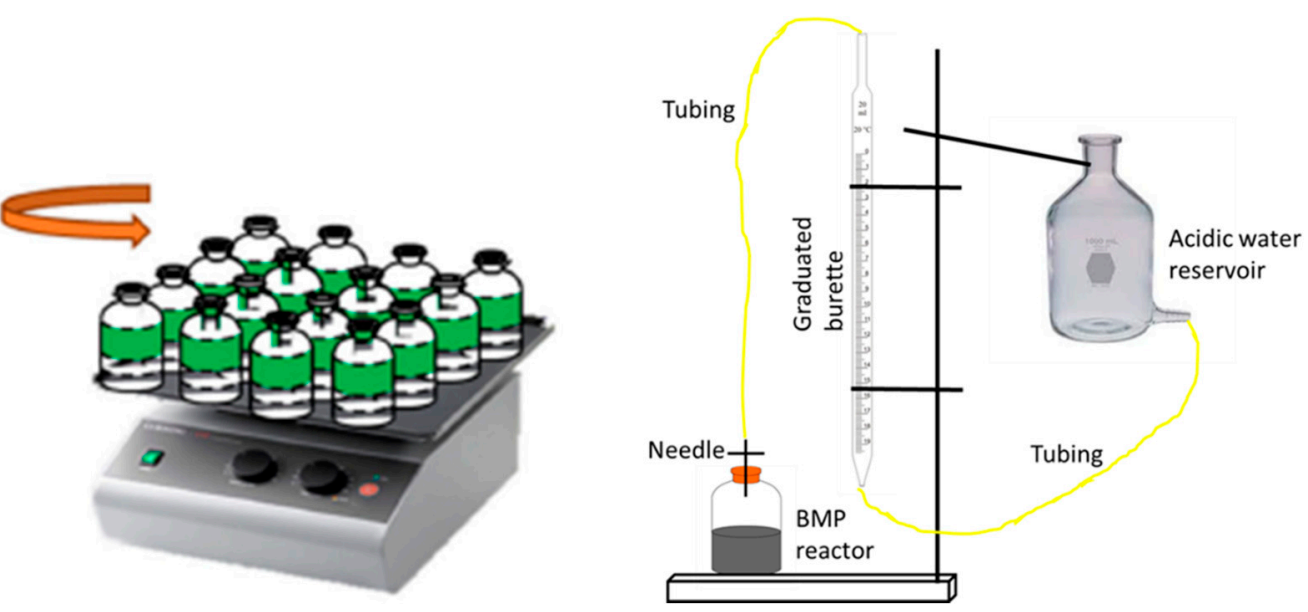

Figure 1. BMP experimental setup and water replacement device used to measure biogas.

\section{Results and Discussion}

\subsection{Biogas Production}

Biogas production was monitored in all reactors until it ceased, which was observed on the 39th and 79th day for the first and second experimental setups, respectively (Figures 2 and 3). The average biogas production in the control reactors was less than $30 \mathrm{~mL}$ for both the experimental setups, and it was subtracted from the average biogas volume generated in all test reactors.

A high initial biogas production rate was observed in all reactors, which corresponds to the anaerobic stabilization of readily soluble substrates. After the soluble part of the substrate was consumed (Day 5, Figures 2 and 3), a decrease in biogas production was observed. This observation can be explained by the lack of readily biodegradable organics and need for hydrolysis and consecutive biogas production later [35]. With the hydrolysis, methane precursors became available for methanogens, and biogas production rate increased in all reactors again (Day 7, Figure 2a; Day 8, Figure 2b; Day 6, Figure 3). The biogas production in all reactors stabilized without a significant change in their trends. After a gradual decrease, the biogas production levels in all reactors levelled off on the 39th and 79th day for the first and second experimental setups, respectively (Figures 2 and 3).

The biogas production levels observed in all reactors varied based on initial COD concentrations as well as biochar, trace metals, and graphene supplementation (Figures 2 and 3). The total biogas production values for all reactors are depicted in Table 3. In order to evaluate the effect of different supplementations, the biogas values in the reactors supplemented with biochar, trace metals, and graphene were normalized relative to the reactors containing only AP (T1, T5, and T9). These reactors were identical to the rest of the reactors except for the supplementation of biochar, trace metals, and graphene (Table 2). 


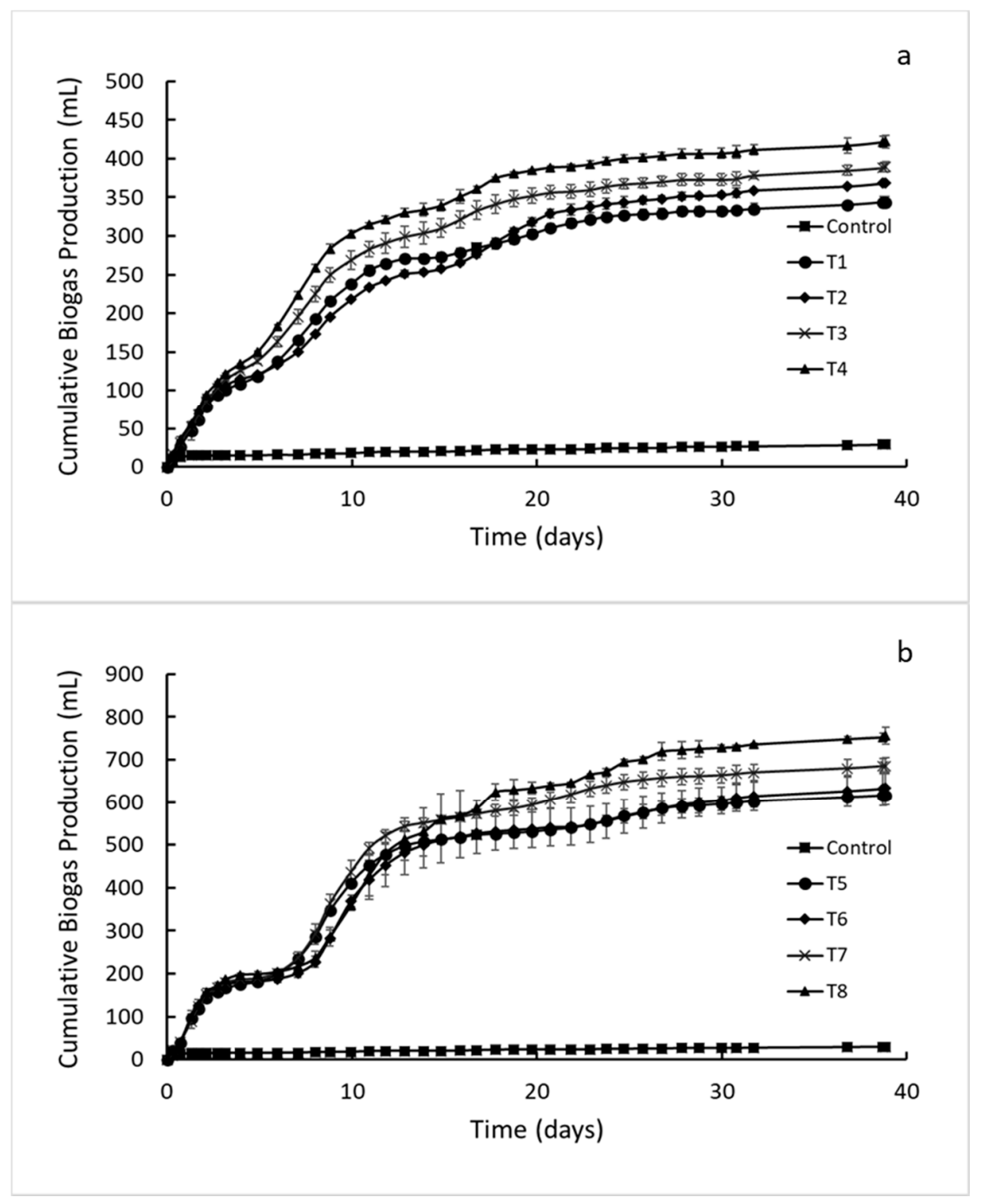

Figure 2. Effect of biochar and trace metals supplementation on biogas production from apple pomace at COD concentrations of (a) 6000 (T1-T4) and (b) 12,000 mg/L (T5-T8).

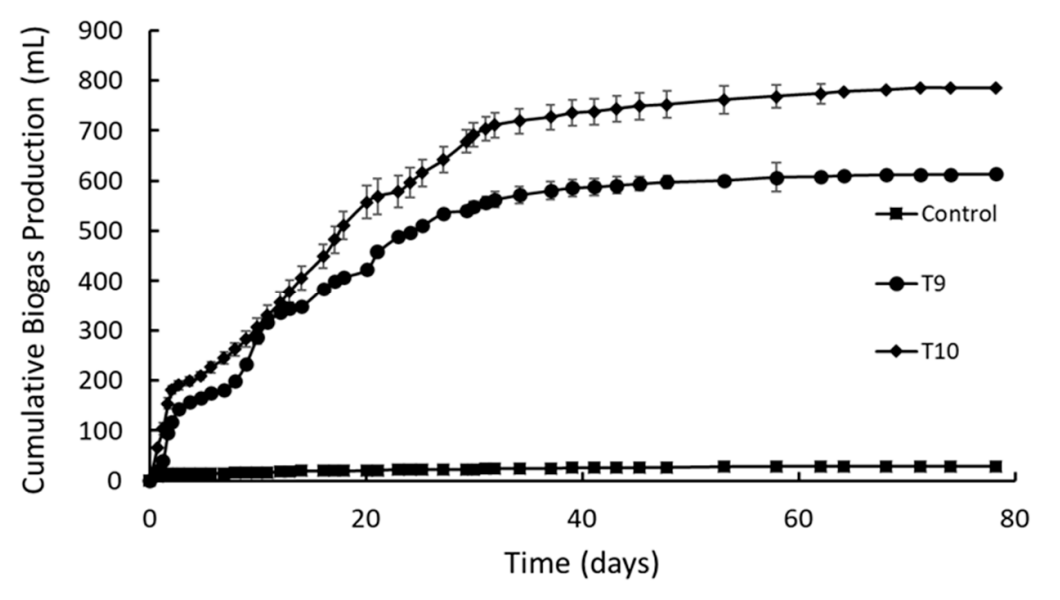

Figure 3. Effect of graphene supplementation on biogas production from apple pomace at a COD concentration of $12,000 \mathrm{mg} / \mathrm{L}$. 
Table 3. Biogas production, methane content, and methane yield observed in reactors.

\begin{tabular}{|c|c|c|c|c|c|c|}
\hline & \multicolumn{3}{|c|}{ Biogas Production } & \multicolumn{3}{|c|}{ Methane Yield } \\
\hline & $\begin{array}{c}\text { Methane } \\
\text { Content (\%) }\end{array}$ & Volume (mL) & $\begin{array}{l}\text { Change Relative to } \\
\text { AP Only Reactor (\%) }\end{array}$ & $\mathrm{mL} \mathrm{CH}_{4} / \mathrm{g} \mathrm{VS}$ & $\begin{array}{c}\mathrm{mL} \mathrm{CH}_{4} / \mathrm{g} \\
\mathrm{COD}\end{array}$ & $\begin{array}{l}\text { Change Relative to } \\
\text { AP Only Reactor (\%) }\end{array}$ \\
\hline $\mathrm{C} 1$ & $62.6 \pm 4.8$ & $29.0 \pm 0.3$ & - & - & - & - \\
\hline $\mathrm{T} 1$ & $61.0 \pm 0.8$ & $343.9 \pm 7.2$ & - & $380.4 \pm 1.8$ & $232.5 \pm 3.6$ & - \\
\hline $\mathrm{T} 2$ & $60.09 \pm 0.8$ & $368.5 \pm 0$ & 7.2 & $401.4 \pm 5.5$ & $245.3 \pm 3.3$ & 5.5 \\
\hline $\mathrm{T} 3$ & $64.1 \pm 1.9$ & $389.5 \pm 6.5$ & 13.3 & $452.6 \pm 5.4$ & $276.6 \pm 2.2$ & 19.0 \\
\hline $\mathrm{T} 4$ & $61.1 \pm 1.7$ & $422.1 \pm 7.9$ & 22.7 & $468.0 \pm 3.6$ & $286.0 \pm 6.2$ & 23.0 \\
\hline $\mathrm{T} 5$ & $64.0 \pm 0.3$ & $617.1 \pm 7.8$ & - & $358.9 \pm 8.1$ & $219.3 \pm 7.7$ & - \\
\hline $\mathrm{T} 6$ & $63.6 \pm 4.9$ & $633.1 \pm 38.8$ & 2.6 & $365.9 \pm 8.9$ & $223.6 \pm 6.0$ & 1.9 \\
\hline $\mathrm{T} 7$ & $61.5 \pm 0.2$ & $685.8 \pm 18.6$ & 11.1 & $382.9 \pm 7.7$ & $234.0 \pm 4.1$ & 6.7 \\
\hline $\mathrm{T} 8$ & $62.5 \pm 0.6$ & $756.0 \pm 19.4$ & 19.4 & $429.5 \pm 4.5$ & $262.5 \pm 0$ & 19.6 \\
\hline $\mathrm{C} 2$ & $61.7 \pm 0.5$ & $32.8 \pm 2.2$ & - & - & - & - \\
\hline T9 & $63.1 \pm 0.9$ & $613.9 \pm 15.7$ & - & $351.6 \pm 3.9$ & $214.8 \pm 9.6$ & - \\
\hline $\mathrm{T} 10$ & $60.2 \pm 1.0$ & $784.8 \pm 17.3$ & 27.8 & $429.0 \pm 6.8$ & $262.2 \pm 0.4$ & 22.0 \\
\hline
\end{tabular}

BMP tests are commonly used for the determination of the methane potential and biodegradability of wastewater and waste biomass. Due to the biological nature of the assay and heterogeneity of feedstocks, high standard deviation values up to $34 \%$ have been reported [36,37]. Similarly, the normalized biogas production values obtained in this study are relatively high (up to $6.1 \%$, Table 2).

The experimental results (Figures 1-3 and Table 3) clearly indicate the positive effect of biochar, trace metals, and graphene on the AD process performance. Trace metal supplementation improved the biogas production by $7.2 \%$ and $2.6 \%$ at initial COD concentrations of 6000 and $12,000 \mathrm{mg} / \mathrm{L}$, respectively. The corresponding methane yield increase was from $380.4 \pm 1.8$ to $401.4 \pm 5.5 \mathrm{~mL} \mathrm{CH}_{4} / \mathrm{g}$ VS at $6000 \mathrm{mg} \mathrm{COD} / \mathrm{L}$. It was from $358.9 \pm 8.1$ to $365.9 \pm 8.9$ at $12,000 \mathrm{mg} \mathrm{COD} / \mathrm{L}$. As these numbers indicate that trace metal supplementation did not lead to a significant improvement in the process performance.

As seen from Table 3, trace metal and biochar supplementation at a COD concentration of $6000 \mathrm{mg} / \mathrm{L}$ resulted in $7.2 \%$ and $13.3 \%$ increases in the biogas production (T2 and T3) relative to the reactors containing only AP (T1), respectively. Supplementing trace metal and biochar together improved biogas production by $22.7 \%$ (T4). This synergistic effect was also observed at the COD concentration of $12,000 \mathrm{mg} / \mathrm{L}$. Trace metal and biochar supplementation led to $2.6 \%$ and $11.1 \%$ increases in biogas production (T6 and T7), respectively, and supplementing them together led to a $19.4 \%$ increase (T8). The improvement in the $\mathrm{AD}$ process performance was significantly higher for graphene supplemented reactors (Figure 4 and Table 3). Graphene supplementation $(666.7 \mathrm{mg} / \mathrm{L})$ enhanced the biogas production by $27.8 \%$. 


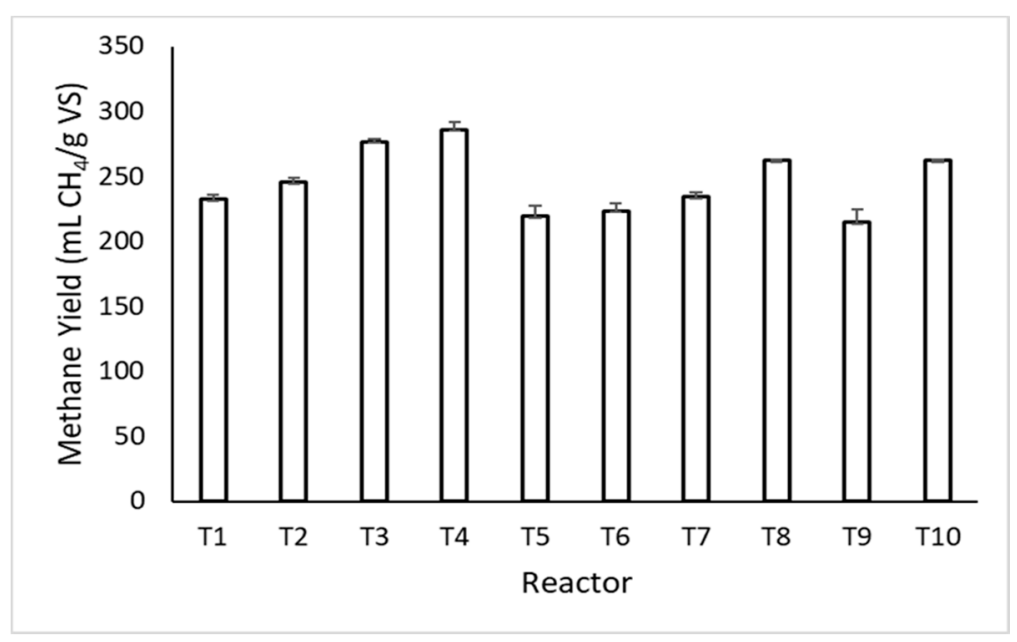

Figure 4. Observed methane yields in all reactors.

\subsection{Methane Yields}

The methane $\left(\mathrm{CH}_{4}\right)$ contents of the biogas produced in the reactors were determined on Day 36 and 50 for the first and second experimental setups, respectively. The average methane content in the reactors ranged between $60.09 \pm 0.8$ and $64.1 \pm 1.9$ (Table 3).

Methane yield or the volume of methane produced per mass of volatile solids or COD is a commonly used parameter to assess the potential energy generation from several feedstocks. Moreover, methane yield offers a unified basis to compare different feedstocks due to their varying levels of solids and COD contents [38,39]. The methane yields for reactors operated in this study were calculated both on a VS and COD basis and are presented in Table 3. Similar to the total biogas production values in Table 3, methane yield values that were also in test reactors were normalized relative to the reactors containing only AP (Table 3).

The methane yields of reactors per mass of volatile solids or COD supplemented with biochar, trace metals, and graphene ranged between $365.9 \pm 8.9$ and $468.0 \pm 3.6 \mathrm{~mL}$ $\mathrm{CH}_{4} / \mathrm{g}$ VS and 223.6 \pm 6.0 and $286.0 \pm 6.2 \mathrm{~mL} \mathrm{CH}_{4} / \mathrm{g}$ COD, respectively (Table 3, Figure 3). Biochar and trace metals supplementation led to $19.6 \%$ and $23.0 \%$ increases in the methane yield relative to the reactor fed only with $\mathrm{AP}$, respectively (T1 and T5, Table 3). Graphene resulted in a $22 \%$ improvement relative to the reactor fed only with AP (T9, Table 3).

Similar to the improvement in biogas production levels, supplementation with trace metals and biochar together resulted in a synergistic effect compared to supplementing them individually. The highest methane yield $\left(468.0 \pm 3.6 \mathrm{~mL} \mathrm{CH}_{4} / \mathrm{g}\right.$ VS and $286.0 \pm 6.2 \mathrm{~mL}$ $\mathrm{CH}_{4} / \mathrm{g}$ COD) was observed for T4, which was supplemented with trace metals and biochar at a COD level of $6000 \mathrm{mg} / \mathrm{L}$. At the higher COD level of 12,000 mg/L, a slight decrease in the methane yield was observed $\left(429.5 \pm 4.5 \mathrm{~mL} \mathrm{CH}_{4} / \mathrm{g}\right.$ VS and $262.5 \pm 0 \mathrm{~mL} \mathrm{CH}_{4} / \mathrm{g}$ COD). This observation may suggest insufficient levels of trace metals and biochar supplementation for the investigated COD concentration.

Kafle and Kim [19] investigated biogas production by anaerobic co-digestion of apple waste (AW) and swine manure (SM) at mesophilic and thermophilic temperatures. The AW was found to be a potential substrate for co-digestion with SM for biogas production. Biogas production in the batch test improved when using a mixture of AW and SM (AW:SM = 33:67, \%VS basis) as opposed to SM only. The methane yield was reported to be $252 \mathrm{~mL} / \mathrm{g}$ TCOD added. This value is in agreement with the findings of this study (Table 3).

Coalla et al. [20] investigated the anaerobic co-digestion of apple pulp and slaughterhouse waste (pig intestine and bovine stomach content). The methane yield was reported to be $525 \mathrm{~mL} / \mathrm{g}$ VS. This value is higher than maximum methane yield observed in this study $(468.0 \pm 3.6 \mathrm{~mL} / \mathrm{g} \mathrm{VS})$. It must be noted the methane percentage of biogas reported by Coalla et al. was around 75\% [20], while it ranged between $60.09 \% \pm 0.8 \%$ and 
$64.1 \% \pm 1.9 \%$ in this study. The difference might be due to co-digestion with slaughterhouse waste.

The methane yield values observed in this study (Figure 4) are in agreement with the findings of $\mathrm{Li}$ et al. [40] who investigated the co-digestion of AP apple pulp, cow slurry, and olive pomace, and reported the highest observed methane yield as $340 \mathrm{~mL} / \mathrm{g}$ VS.

Moreover, the methane yield values obtained for AP in this study are significantly higher than methane yield values $(160-350 \mathrm{~mL} / \mathrm{g}$ VS) reported for several fruit and vegetable wastes [41-46].

DIET is a syntrophic metabolism in which free electrons flow from one cell to another without being shuttled by reduced molecules. It is a more effective mechanism for interspecies electron exchange under anaerobic conditions than interspecies electron transfer (IIET) via reduced molecules such as hydrogen and formate. There are many studies in the literature indicating that conductive materials (biochar, magnetite, granular activated carbon, graphene, etc.) supplementation in AD may facilitate DIET and significantly improve its performance $[31,32,47,48]$. Even though investigating the potential DIET mechanism was not within the scope of this study, it was speculated that the observed improvement in performance for $\mathrm{AD}$ of AP was due to the DIET mechanism. The microbial community must be investigated in future studies to confirm this speculation.

\section{Conclusions}

This study investigated the supplementation of carbon-based conductive materials and trace metals to improve the anaerobic digestion of apple pomace for the first time.

The supplementation with biochar, trace metals, and graphene improved the biogas production from AP. The corresponding methane yields were also higher than in the reactors operated in the absence of these additives. Trace metal and biochar supplementation at a COD concentration of $6000 \mathrm{mg} / \mathrm{L}$ resulted in $7.2 \%$ and $13.3 \%$ increases in biogas production, respectively. When trace metals and biochar were supplemented together, biogas production increased by $22.7 \%$. This synergistic effect was also observed at a COD concentration of $12,000 \mathrm{mg} / \mathrm{L}$. The improvement in the biogas formation was significantly higher for graphene-supplemented reactors $(27.8 \%)$.

Moreover, biochar and trace metals supplementation also led to $19.6 \%$ and $23.0 \%$ increases in the methane yield relative to the reactor fed only with $\mathrm{AP}$, respectively. Graphene resulted in a $22 \%$ improvement relative to the reactor fed only with AP.

The highest methane yield $\left(468.0 \pm 3.6 \mathrm{~mL} \mathrm{CH}_{4} / \mathrm{g} \mathrm{VS}\right.$ and $\left.286.0 \pm 6.2 \mathrm{~mL} \mathrm{CH}_{4} / \mathrm{g} \mathrm{COD}\right)$ was observed for the reactor that was supplemented with trace metals and biochar at a COD level of $6000 \mathrm{mg} / \mathrm{L}$. At the higher COD level of $12,000 \mathrm{mg} / \mathrm{L}$, a slight decrease in the methane yield was observed ( $429.5 \pm 4.5 \mathrm{~mL} \mathrm{CH}_{4} / \mathrm{g}$ VS and $262.5 \pm 0 \mathrm{~mL} \mathrm{CH}_{4} / \mathrm{g} \mathrm{COD}$ ).

These results indicate that anaerobic digestion supplemented with carbon-based conductive materials and trace metals is a viable option for valorizing apple pomace. This not only represents a sustainable waste management approach for apple pomace but also reduces greenhouse gasses and generates renewable energy in the form of methane.

Author Contributions: A.C., L.M. and S.U.-D. conducted the experiments and collected data. S.U.-D. and G.N.D. planned the research and designed the experiments, analyzed data and wrote the article. All authors have read and agreed to the published version of the manuscript.

Funding: This research was funded by Central Michigan University's Office of Research and Graduate Studies.

Institutional Review Board Statement: Not applicable.

Informed Consent Statement: Not applicable.

Acknowledgments: The authors thank Daniel Zitomer (Marquette University) for providing the biochar used in the experiments.

Conflicts of Interest: The authors declare no conflict of interest. 


\section{References}

1. Indu Parmar, H.P.; Rupasinghe, V. Bio-conversion of apple pomace into ethanol and acetic acid: Enzymatic hydrolysis and fermentation. Bioresour. Technol. 2013, 130, 613-620. [CrossRef]

2. Carson, K.J.; Collins, J.L.; Penfield, M.P. Unrefined, dried apple pomace as a potential food ingredient. J. Food Sci. 1994, 59, 1213-1215. [CrossRef]

3. Suarez, B.; Alvarez, A.L.; Garcia, Y.D.; Barrio, G.d.; Lobo, A.P.; Parra, F. Phenolic profiles, antioxidant activity and in vitro antiviral properties of apple pomace. Food Chem. 2010, 120, 339-342. [CrossRef]

4. Kennedy, M.; List, D.; Lu, Y.; Foo, L.Y.; Newman, R.H.; Sims, I.M.; Bain, P.J.S.; Halminton, B.; Fenton, G. Apple pomace and products derived from apple pomace: Uses, composition and analysis. In Modern Methods of Plant Analysis: Analysis of Plant Waste Materials; Linskens, H.F., Jackson, J.F., Eds.; Springer: Berlin, Germany, 1999; pp. 75-119.

5. Das, R.K.; Brar, S.K.; Verma, M. A fermentative approach towards optimizing directed biosynthesis of fumaric acid by Rhizopus oryzae 1526 utilizing apple industry waste biomass. Fungal Biol. 2015, 119, 1279-1290. [CrossRef] [PubMed]

6. Gassara, F.; Brara, S.K.; Pelletier, F.; Vermab, M.; Godboutb, S.; Tyagi, R.D. Pomace waste management scenarios in QuébecImpact on greenhouse gas emissions. J. Hazard. Mat. 2011, 192, 1178-1185. [CrossRef]

7. Vendruscolo, F.; Albuquerque, P.M.; Streit, F.; Esposito, E.; Ninow, J.L. Apple pomace: A versatile substrate for biotechnological applications. Crit. Rev. Biotechnol. 2008, 28, 1-12. [CrossRef] [PubMed]

8. Molinuevo-Salces, B.; Riaño, B.; Hijosa-Valsero, M.; González-García, I.; Paniagua-García, A.; Hernández, D.; Garita-Cambronero, J.; Díez-Antolínez, R.; García-González, M.C. Valorization of apple pomaces for biofuel production: A biorefinery approach. Biomass Bioenergy 2020, 142, 105785. [CrossRef]

9. Duan, Y.; Mehariya, S.; Kumar, A.; Singh, E.; Yang, J.; Kumar, S.; Li, H.; Awasthi, M.K. Apple orchard waste recycling and valorization of valuable product-A review. Bioengineered 2021, 12, 476-495. [CrossRef]

10. Akturk, A.S.; Demirer, G.N. Improved food waste stabilization and valorization by anaerobic digestion through supplementation of conductive materials and trace elements. Sustainability 2020, 12, 5222. [CrossRef]

11. Tampio, E.; Ervasti, S.; Paavola, T.; Heaven, S.; Banks, C.; Rintala, J. Anaerobic digestion of autoclaved and untreated food waste. Waste Manag. 2014, 34, 370-377. [CrossRef]

12. Erguder, T.H.; Demirer, G.N. Organic acid production from the organic fraction of municipal solid waste and cow manure in leaching bed reactors. Environ. Eng. Manag. J. 2016, 15, 2487-2495.

13. Calicioglu, O.; Demirer, G.N. Biogas production from waste microalgal biomass obtained from nutrient removal of domestic wastewater. Waste Biomass Valoriz. 2016, 7, 1397-1408. [CrossRef]

14. Ramírez-Arpide, F.R.; Demirer, G.N.; Gallegos-Vázquez, C.; Hernández-Eugenio, G.; Santoyo-Cortés, V.H.; Espinosa-Solares, T. Life cycle assessment of biogas production through anaerobic co-digestion of nopal cladodes and dairy cow manure. J. Clean. Prod. 2018, 172, 2313-2322. [CrossRef]

15. Gur, E.; Demirer, G.N. Anaerobic digestibility and biogas production capacity of pistachio processing wastewater in UASB reactors. J. Environ. Eng. 2019, 145, 8. [CrossRef]

16. Jewell, W.J.; Cummings, R.J. Apple pomace energy and solids recovery. J. Food Sci. 1984, 49, 407-410. [CrossRef]

17. Dubrovskis, V.; Plume, I. Biogas from wastes of pumpkin, marrow and apple. Agron. Res. 2017, 15, 69-78.

18. Tulun, S.; Bilgin, M. Enhanced soluble protein and biochemical methane potential of apple biowaste by different pretreatment. Earth Sys. Environ. 2018, 2, 85-94. [CrossRef]

19. Kafle, G.K.; Kim, S.H. Anaerobic treatment of apple waste with swine manure for biogas production: Batch and continuous operation. Appl. Energy 2013, 103, 61-72. [CrossRef]

20. Coalla, H.L.; Blanco Fernández, J.M.; Morís Morán, M.A.; López Bobo, M.R. Biogas generation apple pulp. Bioresour. Technol. 2009, 100, 3843-3847. [CrossRef]

21. Appels, L.; Lauwers, J.; Degreve, J.; Helsen, L.; Lievens, B.; Willems, K.; Impe, J.V.; Dewil, R. Anaerobic digestion in global bio-energy production: Potential and research challenges. Renew. Sustain. Environ. Rev. 2011, 15, 4295-4301. [CrossRef]

22. Prajapati, K.B.; Singh, R. Enhancement of biogas production in bio-electrochemical digester from agricultural waste mixed with wastewater. Renew. Energy. 2020, 146, 460-468. [CrossRef]

23. Liu, J.; Yang, M.; Zhang, J.; Zheng, J.; Xu, H.; Wang, Y.; Wei, Y. A comprehensive insight into the effects of microwave- $\mathrm{H}_{2} \mathrm{O}_{2}$ pretreatment on concentrated sewage sludge anaerobic digestion based on semi-continuous operation. Bioresour. Technol. 2018, 256, 118-127. [CrossRef]

24. Dai, X.H.; Duan, N.; Dong, B.; Dai, L.L. High-solids anaerobic co-digestion of sewage sludge and food waste in comparison with mono digestions: Stability and performance. Waste Manag. 2012, 33, 308-316. [CrossRef] [PubMed]

25. Tojo, G.C.; Moscoviz, R.; Ruiz, D.; Catalina, G.S.; Trably, E.; Rouez, M.; Crest, M.; Steyer, J.P.; Bernet, N.; Delgenes, J.P.; et al. Addition of granular activated carbon and trace elements to favor volatile fatty acid consumption during anaerobic digestion of food waste. Bioresour. Technol. 2018, 260, 157-168. [CrossRef] [PubMed]

26. Zhang, W.; Wu, S.; Guo, J.; Zhou, J.; Dong, R. Performance and kinetic evaluation of semi-continuously fed anaerobic digesters treating food waste: Role of trace elements. Bioresour. Technol. 2015, 178, 297-305. [CrossRef]

27. Barua, S.; Dhar, B.R. Advances towards understanding and engineering direct interspecies electron transfer in anaerobic digestion. Bioresour. Technol. 2017, 244, 698-707. [CrossRef] [PubMed] 
28. Viggi, C.C.; Simonetti, S.; Palma, E.; Pagliaccia, P.; Braguglia, C.; Fazi, S.; Aulenta, F. Enhancing methane production from food waste fermentate using biochar: The added value of electrochemical testing in pre-selecting the most effective type of biochar. Biotechnol. Biofuels 2017, 10, 303. [CrossRef]

29. Wang, G.; Li, Q.; Gao, X.; Wang, X.C. Synergetic promotion of syntrophic methane production from anaerobic digestion of complex organic wastes by biochar: Performance and associated mechanisms. Bioresour. Technol. 2017, 250, 812-820. [CrossRef]

30. Park, J.; Kang, H.; Park, K.; Park, H. Direct interspecies electron transfer via conductive materials: A perspective for anaerobic digestion applications. Bioresour. Technol. 2018, 254, 300-311. [CrossRef]

31. Lin, R.; Cheng, J.; Zhang, J.; Zhou, J.; Cen, K.; Murphy, J.D. Boosting biomethane yield and production rate with graphene: The potential of direct interspecies electron transfer in anaerobic digestion. Bioresour. Technol. 2017, 239, 345-352. [CrossRef]

32. Tian, T.; Qiao, S.; Li, X.; Zhang, M.; Zhou, J. Nano-graphene induced positive effects on methanogenesis in anaerobic digestion. Bioresour. Technol. 2017, 224, 41-47. [CrossRef] [PubMed]

33. Baird, R.; Bridgewater, L. Standard Methods for the Examination of Water and Wastewater, 23rd ed.; American Public Health Association: Washington, DC, USA, 2017.

34. Achinas, S.; Euverink, G.J.W. Elevated biogas production from the anaerobic co-digestion of farmhouse waste: Insight into the process performance and kinetics. Waste Manag. Res. 2019, 37, 1240-1249. [CrossRef] [PubMed]

35. Zhao, M.X.; Ruan, W.Q. Biogas performance from co-digestion of Taihu algae and kitchen wastes. Energy Convers. Manag. 2013, 75, 21-24. [CrossRef]

36. Raposo, F.; Fernández-Cegrí, V.; De la Rubia, M.A.; Borja, R.; Béline, F.; Cavinato, C.; Demirer, G.; Fernández, B.; FernándezPolanco, M.; Frigon, J.C.; et al. Biochemical methane potential (BMP) of solid organic substrates: Evaluation of anaerobic biodegradability using data from an international inter-laboratory study. J. Chem. Technol. Biotechnol. 2011, 86, 1088-1098. [CrossRef]

37. Pham, C.H.; Triolo, J.M.; Cu TT, T.; Pedersen, L.; Sommer, S.G. Validation and recommendation of methods to measure biogas production potential of animal manure. Asian-Australas J. Anim. Sci. 2013, 26, 864-873. [CrossRef] [PubMed]

38. Brown, D.; Li, Y. Solid state anaerobic co-digestion of yard waste and food waste for biogas production. Bioresour. Technol. 2013, 127, 275-280. [CrossRef]

39. Meng, Y.; Li, S.; Yuan, H.; Zou, D.; Liu, Y.; Zhu, B.; Chufo, A.; Jaffar, M.; Li, X. Evaluating biomethane production from anaerobic mono- and co-digestion of food waste and floatable oil (FO) skimmed from food waste. Bioresour. Technol. 2015, 185, 7-13. [CrossRef]

40. Li, K.; Liu, R.; Cui, S.; Yu, Q.; Ma, R. Anaerobic co-digestion of animal manures with corn stover or apple pulp for enhanced biogas production. Renew. Energy 2018, 118, 335-342. [CrossRef]

41. Labatut, R.; Angenent, L.T.; Scott, N. Biochemical methane potential and biodegradability of complex organic substrates. Bioresour. Technol. 2011, 102, 2255-2264. [CrossRef]

42. Lin, J.; Zuo, J.; Gan, L.; Li, P.; Liu, F.; Wang, K.; Chen, L.; Gan, H. Effects of mixture ratio on anaerobic co-digestion with fruit and vegetable waste and food waste of China. J. Environ. Sci. 2011, 23, 1403-1408. [CrossRef]

43. Shen, F.; Yuan, H.; Pang, Y.; Chen, S.; Zhu, B.; Zou, D.; Liu, Y.; Ma, J.; Yu, L.; Li, X. Performances of anaerobic co-digestion of fruit \& vegetable waste (FVW) and food waste (FW): Single-phase vs. two-phase. Bioresour. Technol. 2013, 144, 80-85. [PubMed]

44. Ziaee, F.; Mokhtarani, N.; Pourrostami Niavol, K. Solid-state anaerobic co-digestion of organic fraction of municipal waste and sawdust: Impact of co-digestion ratio, inoculum-to-substrate ratio, and total solids. Biodegradation 2021, 32, 299-312. [CrossRef] [PubMed]

45. Zia, M.; Ahmed, S.; Kumar, A. Anaerobic digestion (AD) of fruit and vegetable market waste (FVMW): Potential of FVMW, bioreactor performance, co-substrates, and pre-treatment techniques. Biomass Conv. Bioref. 2020. [CrossRef]

46. Ambaye, T.G.; Rene, E.R.; Dupont, C.; Wongrod, S.; van Hullebusch, E.D. Anaerobic digestion of fruit waste mixed with sewage sludge digestate biochar: Influence on biomethane production. Front. Energy Res. 2020, 8, 31. [CrossRef]

47. Yang, Y.; Zhang, Y.; Li, Z.; Zhao, Z.; Quan, X.; Zhao, Z. Adding granular activated carbon into anaerobic sludge digestion to promote methane production and sludge decomposition. J. Clean. Prod. 2017, 149, 1101-1108. [CrossRef]

48. Rasapoor, M.; Young, B.; Asadov, A.; Brar, R.; Sarmah, A.K.; Zhuang, W.Q.; Baroutian, S. Effects of biochar and activated carbon on biogas generation: A thermogravimetric and chemical analysis approach. Energy Convers. Manag. 2020, 203, 112221. [CrossRef] 